\title{
Горлова Н.В. Толерантность к неопределенности как индиви- дуально-личностная предпосылка процесса самоопределения в подростковом возрасте, ранней и поздней юности
}

\section{Gorlova N.V. Tolerance for ambiguity as individual personality presupposition of the process of self-determination in adolescence and youth}

Красноярский краевой институт повышения квалификации, Красноярск, Россия

\begin{abstract}
Современная ситуация развития в подростковом и юношеском возрастах характеризуется изменчивостью норм и ценностей, высокой степенью новизны и сложности. Толерантность к неопределенности полагается в данной статье индивидуально-личностной предпосылкой процесса самоопределения. Цель данного исследования - изучение специфики толерантности к неопределенности в подростковом возрасте, ранней и поздней юности у представителей мужского и женского пола, а также выявление специфики связей толерантности к неопределенности с интернальностью и смысложизненными ориентациями по полу на каждом из указанных возрастных этапов.
\end{abstract}

Выборка исследования: 322 человека (191 респондент женского пола, 131 респондент мужского пола): 1) 117 участников подросткового возраста (ср. возраст - 15,4 года); 2) 114 участников ранней юности (ср. возраст - 16,3 года); 3) 100 участников поздней юности (ср. возраст - 18,1 года). Методики исследования: 1. Тест смысложизненных ориентаций (СЖО) [Леонтьев, 2006]. 2. Метод исследования уровня субъективного контроля (УСК) [Бажин и др., 1984]. 3. Методика диагностики толерантности к неопределенности (Баднер С., в адаптации Солдатовой Г.У., Шайгеровой Л.А., Прокофьевой Т.Ю., Кравцовой О.А.) [Психодиагностика толерантности личности, 2008].

Результаты: сравнительное исследование толерантности к неопределенности по полу на выборках подросткового возраста, ранней и поздней юности показало более выраженную толерантность к неопределенности у представителей женского пола во всех изученных возрастных периодах. Респонденты женского пола более, чем респонденты мужского пола, толерантны к неопределенности и к новизне в подростковом возрасте и в ранней юности. Обнаружены связи толерантности к неопределенности с интернальным локусом контроля и смысложизненными ориентациями у представителей женского и мужского пола в подростковом возрасте, связи толерантности к неопределенности с интернальным локусом контроля у представителей женского пола в поздней юности.

Ключевые слова: толерантность к неопределенности, интернальный локус контроля, смысложиз- 
Горлова Н.В. Толерантность к неопределенности как индивидуально-личностная предпосылка... ненные ориентации, самоопределение, различия по полу, подростковый возраст, юношеский возраст

Современное транзитивное общество предлагает молодым людям проходить жизненное и профессиональное самоопределение в условиях социальной неопределенности - постоянной изменчивости ценностей и норм. К этому добавляется и специфика социальной ситуации развития в определенные возрастные периоды. Согласно С.А.Хазовой, в каждом возрасте существуют ситуации вызовов (неопределенности), когда к системе ресурсов субъекта предъявляются особые, повышенные требования. Это ситуации трудные (стрессовые) жизненные, а также ситуации достижений (в учебной, профессиональной и других деятельностях) [Хазова, 2014]. Кроме того, выбор, совершаемый в процессе жизненного, личностного и профессионального самоопределения, можно отнести к личностному, экзистенциальному выбору, характерному для критических ситуаций человеческого существования [Leontiev, 1994, p. 53; Леонтьев, Шелобанова, 2001, с. 58]. Он предполагает ответственный выбор при отсутствии или неполноте альтернатив, когда субъект выбирает между несколькими возможными будущими, и реализация этого выбора - это конструирование того будущего, которое было выбрано. Таким образом, социальная ситуация развития отмечена ситуациями вызовов, ситуаций высокой неопределенности и новизны, необходимости делать экзистенциальный выбор будущего.

Самоопределяться в такой ситуации сложно, так как вовне нет основы и какой-то структуры, на которую можно было бы опереться. Согласно экзистенциальной психологии, так личность сталкивается с данностью свободы и возникает экзистенциальный конфликт. Реакцией на увеличение транзитивности и неопределенности становится появление внутренних опор. В данной работе таким внутренним личностным ресурсом, который помогает взрослеющим людям самоопределяться, продолжать действовать в непростых условиях и даже получать удовольствие от преодоления неопределенности через ее принятие, является толерантность к неопределенности. Подростковый возраст, юношеский возраст - это периоды самоопределения взрослеющей личности, совершения ею выбора жизненного и 
Горлова Н.В. Толерантность к неопределенности как индивидуально-личностная предпосылка... профессионального пути. Изучение индивидуально-личностных особенностей процесса самоопределения, их половозрастной специфики является важным этапом исследования самоопределения для понимания этого процесса и выстраивания его наиболее оптимальным для взрослеющей личности образом.

Интернальность, толерантность к неопределенности и осмысленность жизни (смысложизненные ориентации) понимаются автором данной работы индивидуально-личностными предпосылками процесса самоопределения в подростковом и юношеском возрасте. Локус контроля, смысложизненные ориентации изучались на выборках подросткового и юношеского возраста [Волочков, Ермоленко, 2004; Дементий, Купченко, 2011; Калитеевская, Леонтьев, 2006; Леонтьев, Шелобанова, 2001; Панцырь, 2012; Сафин, Нурлыгаянов, 2008; Тропотяга, 2008]. Толерантность к неопределенности, напротив, практически не исследовалась в русле психологии развития.

Значимость этой личностной переменной для развития в этот период может быть понята, исходя из значения толерантности к неопределенности в ситуациях высокого уровня субъектной значимости, к которым относятся выбор места обучения, выбор специальности, которые происходят в подростковом и юношеском периодах взросления. Исследования ситуаций с различными уровнями значимости для субъекта выбора показали, что толерантность к неопределенности выступает как ключевая предпосылка готовности к субъектному выбору в ситуациях высокого уровня значимости [Леонтьев и др., 2019, с. 360].

\section{Значение толерантности к неопределенности для процесса самоопреде- ления в подростковом возрасте, ранней и поздней юности}

В исследованиях толерантность к неопределенности рассматривается как установка личности по отношению к неопределенности [Луковицкая, 1998; Сырцова, 2008]. Также толерантность к неопределенности полагается сегодня как компонент диалектического понимания. Как пишет С.Л.Блинникова, «диалектическое понимание являет собой готовность субъекта осмысленно жить и продуктивно действовать в условиях противоречий, то есть готовность совершать определенным образом направленную деятельность, которая стабилизует процесс ее осуществления в целом - смысловую установку» [Блинникова, 2012, c. 58]. 
Горлова Н.В. Толерантность к неопределенности как индивидуально-личностная предпосылка... Значение неопределенности для развития личности подчеркивается многими экзистенциально ориентированными психологами, которые говорят, что жизнь человека непостоянна, ее условия и ситуации все время меняются, а неопределенность - естественная среда человеческого существования: «Ненадежность - вот цена, которую платит человек за сознание» [Фромм, 2004, с. 96]; дорога к смыслу «не предопределена: то, что связано с будущим, всегда открыто» [Лэнгле, 2011, с. 23]; «В экзистенции неизбежно присутствует свобода, и с ней - неопределенность» [Ялом, 1999, с. 33].

Кроме того, как было сказано выше, выбор, который совершается в процессе жизненного, личностного и профессионального самоопределения, можно отнести к личностному, экзистенциальному выбору [Leontiev, 1994, p. 53; Леонтьев, Шелобанова, 2001, с. 58], выбору между несколькими возможными будущими.

При рассмотрении толерантности к неопределенности обратимся к одной из статей В.П.Зинченко. В деятельности главным средством преодоления неопределенности является смысл. Как пишет В.П.Зинченко, «означение смысла - лишь половина дела, за которой необходима следующая фаза - рефлексивное осмысление полученного результата, т.е. осмысление значения. Вместе эти противоположно и, возможно, даже иногда одновременно совершающиеся акты составляют существо, ткань механизма понимания» [Зинченко, 2007, с. 15]. Лучшими способами преодоления неопределенности являются, по мнению В.П.Зинченко, различные чувства, а также признание существования неопределенности, а также свободное, а не детерминированное действие.

Как замечает автор, парадокс состоит в том, что даже успешное преодоление порождает новые формы неопределенности, а сама неопределенность характерна для любой ситуации развития и становления человека. Именно неопределенность окружения, требующая вариативности поведения, - это основание свободы и творчества [Там же].

Близким к данному размышлению является идея В.А.Петровского о человеке как субъекте активности в его концепции «надситуативной активности». Он говорит, что именно свободное принятие на себя ответственности за не предрешенный заранее исход действования - это маркер рождения человека субъектом активности [Петровский, 2010, с. 74].

Г.М.Андреева указывает на неопределенность ситуации, в которой личности приходится жить и действовать. Согласно автору, эта неопределенность обусловлена новизной, слож- 
Горлова Н.В. Толерантность к неопределенности как индивидуально-личностная предпосылка... ностью и противоречивостью жизни современного человека и задается темпом социальных изменений, «их разнонаправленностью и процессами глобализации во всех ее проявлениях (экономики, политических решений, культуры), возникновением в качестве результата социальной нестабильности» [Андреева, 2009, с. 79].

По данным А.Р.Баташева, именно «в ситуациях неопределенности наиболее явно проступает внутренняя расположенность субъекта к действиям тем или иным образом, к проявлению присущих именно ему тенденций определения - описания, а отчасти и формирования окружающего социума. В этой ситуации проявляется способность быть режиссером самому себе, а также и окружающим людям» [Баташев, 2008, с. 135].

Необходимо пояснить, что представляет собой такое качество, как толерантность к неопределенности. В нескольких работах [Корнилова, 2010; Кроник, Ахмеров, 2008] указывается, что конструкт толерантности к неопределенности впервые был рассмотрен в двух статьях Э.Френкель-Брунсвик. Вслед за Дж.Брунером А.А.Кроник и Р.А.Ахмеров пишут, что Э.Френкель-Брунсвик не только ввела в психологию термин «нетерпимость к неопределенности», но и также экспериментально выделила два типа людей: а) авторитарная, ригидная личность, нетерпимая к неопределенности; б) ее противоположность - гибкая, толерантная личность, терпимая к неопределенности [Брунер, цит. по: Кроник, Ахмеров, 2008].

Именно после этих публикаций, как указывает Т.В.Корнилова, в науке сложилась дихотомия понимания толерантности к неопределенности как tolerance for ambiguity - толерантности к неясности, двусмысленности, многозначности стимулов, сложности их интерпретации и tolerance for uncertainty - толерантности к неуверенности при недостаточной информированности [Корнилова, 2010, с. 6]. К примеру, в концепции С.Баднера толерантность к неопределенности рассматривается именно в значении tolerance for ambiguity - как личностная черта - толерантность к неопределенным ситуациям, для которых характерны новизна, противоречивость и сложность.

Традиционно, говоря о «толерантности к неопределенности», понимают, что такие люди не просто терпимы к неопределенности, но позитивно принимают и даже активно ищут ее. Также они способны принимать конфликт и напряжение, возникающие в ситуациях двусмысленной, несвязной и противоречивой информации. В целом они способны принимать неизвестность и готовы активно действовать и осуществлять выборы при очевид- 
Горлова Н.В. Толерантность к неопределенности как индивидуально-личностная предпосылка... но неоднозначной ситуации [Смирнов и др., 2016, с. 9-10]. Также авторы подчеркивают, что неопределенность нравится человеку с высокой степенью толерантности к неопределенности: такой человек испытывает чувство удовольствия, принимая неопределенность как вызов собственным возможностям, как успешное преодоление неопределенности, как достижение поставленной цели при максимальной мобилизации своих сил [Там же].

А.Бадью пишет о «готовности к событию» как об особенной стратегии человека, который готов к ситуации неопределенности [Леонтьев, 2015]. Д.А.Леонтьев, рассматривая это понятие, говорит, что быть готовым к событию - это быть готовым к разнообразию возможностей, быть готовым к действиям и реализации выбора в настоящий момент, быть готовым сделать заранее неопределенный выбор. Положительный потенциал этой неопределенности очень важен для человека, поэтому необходимо вырабатывать адекватную к неопределенности, принимающую, позицию.

Толерантность к неопределенности в целом и толерантность к новым ситуациям в частности будет способствовать совершению взрослеющей личностью экзистенциальных выборов при неполноте альтернатив, а также прохождению «перехода» в виде определенных аттестационных процедур в виде соответствия новым требованиям ступени образования, в виде адаптации к новому статусу.

\section{Значение личной ответственности для процесса самоопределения в под- ростковом возрасте, ранней и поздней юности}

В работе полагается, что прохождению процесса самоопределения в подростковом возрасте, ранней и поздней юности способствует вера человека в то, что его судьба - в его руках, что он является творцом своей собственной жизни. Согласно Дж.Роттеру, обобщенное ожидание людей, что они контролируют свою жизнь, выражается в психологии через конструкт, называемый локусом контроля. Именно интернальный локус контроля, по мнению Д.А.Леонтьева, И.Ялома, является наиболее адекватным психометрическим эквивалентом ответственности.

О возможной связи локуса контроля с толерантностью к неопределенности пишет В.П.Зинченко, рассматривая примеры преодоления неопределенности. Он показывает, что человек может справляться с неопределенностью на личностном уровне, имея внутрен- 
Горлова Н.В. Толерантность к неопределенности как индивидуально-личностная предпосылка... ний, интернальный локус контроля, то есть тот, кто понимает, что его достижения и ошибки - это результат собственного волевого усилия, умений, желания или просчетов [Зинченко, 2007, с. 11].

Теория самодетерминации [Ryan, Deci, 2000], подход личностного потенциала и становления самодетерминации [Леонтьев и др., 2011] также рассматривают локус контроля в качестве маркера личной ответственности, автономии личности.

Готовность отвечать за себя (ответственность вообще и ответственность за свои достижения и неудачи) - это такой личностный ресурс, который будет способствовать проявлению субъектной позиции в индивидуальном движении взрослеющей личности.

\section{Значение смысложизненных ориентаций для процесса самоопределения в подростковом возрасте, ранней и поздней юности}

Согласно Д.А.Леонтьеву, смысл жизни можно в феноменологическом аспекте определить как «более или менее адекватное переживание интенциональной направленности собственной жизни» [Леонтьев, 2007, с. 249]. Насыщенность реальной повседневной жизни реальным смыслом оказывается важнее, чем осознанное представление о смысле собственного бытия. Однако задачу на осознание смысла своей жизни могут ставить перед человеком как реальные жизненные ситуации, так и психологические исследования, как уточняет Д.А.Леонтьев.

Смысложизненные ориентации, связанные с временным измерением, анализируются в исследованиях через шкалы адаптированного автором опросника «Цели в жизни» Дж.Крамбо и Л.Махолика [Crumbaugh, Maholick, 1964]. Так, к примеру, шкалой «Цели в жизни» характеризуется наличие или отсутствие в жизни человека целей в будущем, придающих жизни осмысленность, направленность и временную перспективу. Выраженность результатов по шкале «Процесс жизни» показывает, насколько интересным, насыщенным эмоционально, наполненным смыслом воспринимается человеком сам процесс жизни. Измерение шкалы «Результативность жизни» отражает оценку пройденного отрезка жизни, ощущение того, насколько продуктивна и осмысленна была прожитая ее часть [Леонтьев, 2006]. 
Горлова Н.В. Толерантность к неопределенности как индивидуально-личностная предпосылка... Смысложизненные ориентации изучаются в современной, как зарубежной, так и отечественной, психологии достаточно широко - исследуются и связи этого конструкта с другими переменными, и возрастная динамика смысложизненных ориентаций, и кросскультурные особенности данного явления. К примеру, результаты кросс-культурного исследования смысложизненных ориентаций студентов [Gorlova et al., 2012] показывают, что, по всей видимости, осмысленность жизни связана с положительным социальнопсихологическим самочувствием молодежи, а также с отсутствием жестких гендерных установок в различных культурах.

На сегодняшний день существует достаточно исследований, показывающих важность наличия целей в жизни в подростковом и юношеском возрастах, связи целей и смыслов жизни, удовлетворенности в жизни в эти периоды развития. В нескольких исследованиях подросткового и юношеского возрастов в русле позитивной психологии [Damon et al., 2003; Tirria, Quinn, 2010; Hill et al., 2010] сделана попытка изучения целей жизни, которые придают жизни осмысленность, а также связь целей жизни этот фрагмент грамматически здесь сочетается только с «придают жизни... связь целей жизни», чего вроде быть не может. Возможно, на самом деле имеется в виду «попытка изучения... также связей целей жизни...» далее по тексту с процессом формирования идентичности. (согласна)

Так, авторы работы, в которой рассматривается развитие целей в течение подросткового возраста [Damon et al., 2003, p. 126], пишут, что молодые люди, у которых есть цели в жизни, имеют более высокую религиозность, интегрированную идентичность и более глубокое чувство осмысленности, чем те, у кого нет таких четких целей. Кроме того, ценность целей для личности распространяется далеко за подростковый возраст, практически на всю жизнь. Авторы дают определение целей жизни, утверждая, что это устойчивое и обобщенное намерение достичь чего-то, что имеет смысл для субъекта и значимость для мира [Там же, р. 121]. Смысл жизни ориентирован на конечность жизни, а цели жизни направлены на достижение чего-то, на индивидуальный прогресс в чем-то.

Основные выводы другого исследования [Bronk et al., 2009] состоят в том, что цели в жизни связаны с высокой удовлетворенностью жизнью в подростковом и юношеском возрастах, в период вхождения во взрослость, а также в зрелости.

Похожие результаты получили и М.Ф.Стигер с соавт. [Steger et al., 2006], которые обнаружили связь осмысленности жизни и удовлетворенности жизнью. Исследование коллекПсихологические исследования 2020 T 13 № 70 
Горлова Н.В. Толерантность к неопределенности как индивидуально-личностная предпосылка... тива авторов [Gillham et al., 2011] на выборке учащихся 9-10-х классов показало, что трансцендентальные сильные стороны характера (такие как смыслы, любовь) предсказывают большую удовлетворенность жизнью у подростков, их субъективное благополучие.

На сегодняшний день вопрос различий по полу в отношении толерантности к неопределенности является открытым. Близкими по смыслу являются результаты исследований по полу в области психологии выбора. Так, сообщается о сильных связях самостоятельности выбора с его значимостью у женщин [Леонтьев и др., 2019, с. 349].

Однако исследований, которые проясняли бы, насколько выраженной является толерантность к неопределенности у девушек и юношей в подростковом возрасте, ранней и поздней юности, при обзоре источников не найдено. Учитывая, что толерантность к неопределенности выступает ключевой предпосылкой готовности к субъектному выбору в ситуациях высокого уровня значимости, изучение ее через призму различий по полу на протяжении подросткового и юношеского возраста видится обоснованным.

\section{Цель и гипотезы исследования}

Цель данного исследования заключается в изучении специфики толерантности к неопределенности в подростковом возрасте, ранней и поздней юности у представителей мужского и женского пола.

Гипотеза данной работы: компоненты толерантности к неопределенности, интернального локуса контроля и смысложизненных ориентаций представлены бо́льшим количеством положительных связей друг с другом у респондентов женского пола в подростковом возрасте, ранней и поздней юности.

\section{Memodbl}

Выборка исследования: всего в исследовании приняли участие 322 человека (191 респондент женского пола, 131 респондент мужского пола) - школьники и студенты, обучающиеся в общеобразовательных школах г. Красноярска и в Сибирском федеральном университете. Выборка представлена участниками: 1) 117 участников подросткового возраста (66 респондентов женского пола, 51 респондент мужского пола; ср. возраст - 15,4 года); 2) 105 участников ранней юности (54 респондента женского пола, 51 респондент мужско- 
Горлова Н.В. Толерантность к неопределенности как индивидуально-личностная предпосылка... го пола; ср. возраст - 16,3 года); 3) 100 участников поздней юности (71 респондент женского пола, 29 респондентов мужского пола; ср. возраст - 18,1 года).

\section{Методики исследования:}

1. Тест смысложизненных ориентаций (СЖО) [Леонтьев, 2006].

2. Метод исследования уровня субъективного контроля (УСК) [Бажин и др., 1984].

3. Методика диагностики толерантности к неопределенности (С.Баднер, в адаптации Солдатовой Г.У., Шайгеровой Л.А., Прокофьевой Т.Ю., Кравцовой О.А.) [Психодиагностика толерантности личности, 2008].

Методы анализа данных: двухфакторный дисперсионный анализ (ANOVA), непараметрический критерий Манна-Уитни, корреляционный анализ с применением коэффициента корреляции г Пирсона.

\section{Результаты исследования}

Двухфакторный дисперсионный анализ (ANOVA) толерантности к неопределенности по возрасту и полу

Для определения вклада возраста и пола в толерантность к неопределенности используется двухфакторный дисперсионный анализ (ANOVA). На основе критерия Левина (р > $0,05)$ дисперсионный двухфакторный анализ (ANOVA) был применен только к тем данным, где выборки статистически достоверно не различаются по дисперсии.

Дисперсионный анализ показал статистически достоверное различие подвыборок, сформированных по полу, по общей интолерантности к неопределенности $(\mathrm{F}(1,321)=8,254$ при $\mathrm{p}=0,004)$. Общая интолерантность к неопределенности ниже у респондентов женского пола по сравнению с респондентами мужского пола на всем протяжении подросткового возраста, ранней и поздней юности (рис. 1).

Различия в выраженности толерантности к неопределенности по полу

Для определения различий в проявлениях толерантности к неопределенности по полу был использован непараметрический критерий Манна-Уитни (тест Ливена не позволил по 
Горлова Н.В. Толерантность к неопределенности как индивидуально-личностная предпосылка... многим шкалам опросников определять различия параметрическими критериями).

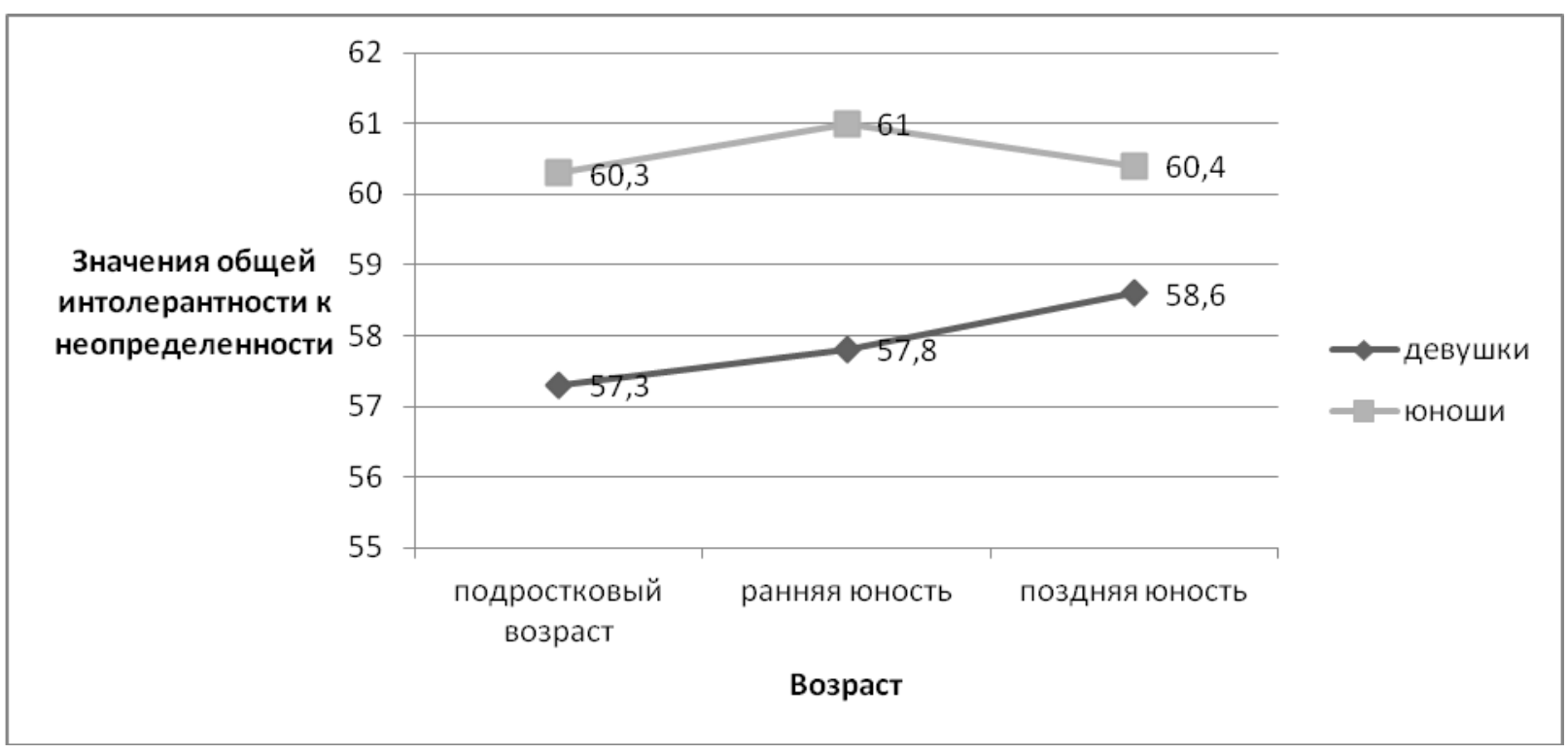

Рис. 1. Средние значения общей интолерантности к неопределенности на разных возрастных группах.

Значимые различия между показателями у респондентов женского пола и респондентов мужского пола в подростковом возрасте (см. табл. 1) обнаружены по общей шкале интолерантности к неопределенности (ИТН), по интолерантности к новизне.

\section{Таблица 1}

Различия средних по интолерантности к неопределенности по полу, подростковый возраст

\begin{tabular}{|l|l|l|l|c|}
\hline Показатель & Группа & $\begin{array}{l}\text { Средние } \\
\text { ранги }\end{array}$ & $\begin{array}{l}\text { Значение } \\
\text { критерия U }\end{array}$ & $\begin{array}{l}\text { Уровень зна- } \\
\text { чимости }\end{array}$ \\
\hline \multirow{2}{*}{$\begin{array}{l}\text { Интолерантность к неопре- } \\
\text { деленности (ИТН) }\end{array}$} & 1 & 52,97 & 1285 & $0,029^{*}$ \\
\cline { 2 - 3 } $\begin{array}{l}\text { Интолерантность к новизне } \\
\text { (ИТН к новизне) }\end{array}$ & 1 & 66,80 & & $0,029 *$ \\
\cline { 2 - 3 } & 2 & 53,00 & 1287 & \\
\hline
\end{tabular}

Примечания. Группа 1 - респонденты женского пола $(\mathrm{n}=66)$; группа 2 - респонденты мужского пола $(\mathrm{n}=51)$. Уровень значимости различий: * $\mathrm{p}<0,05$.

Значимые различия между показателями у респондентов женского пола и респондентов мужского пола ранней юности (см. табл. 2) обнаружены по общей шкале интолерантности к неопределенности (ИТН), по интолерантности к новизне. 
Горлова Н.В. Толерантность к неопределенности как индивидуально-личностная предпосылка...

\section{Таблица 2}

Различия средних по диспозиционной готовности по полу, ранняя юность

\begin{tabular}{|l|l|l|l|l|}
\hline Показатель & Группа & $\begin{array}{l}\text { Средние } \\
\text { ранги }\end{array}$ & $\begin{array}{l}\text { 3начение } \\
\text { критерия U }\end{array}$ & $\begin{array}{l}\text { Уровень } \\
\text { значимости }\end{array}$ \\
\hline $\begin{array}{l}\text { Интолерантность к неопреде- } \\
\text { ленности (ИТН) }\end{array}$ & 1 & 46,91 & 1048 & $0,035^{*}$ \\
\cline { 1 - 3 } $\begin{array}{l}\text { Интолерантность к новизне } \\
\text { (ИТН к новизне) }\end{array}$ & 2 & 59,45 & $0,000 * *$ \\
\cline { 2 - 3 } & 2 & 61,60 & 761,5 &
\end{tabular}

Примечания. Группа 1 - респонденты женского пола $(\mathrm{n}=54)$; группа 2 - респонденты мужского пола $(\mathrm{n}=51)$. Уровень значимости различий: * $\mathrm{p}<0,05 ; * * \mathrm{p}<0,01$.

Таким образом, в подростковом возрасте различия по полу обнаружены по интолерантности к неопределенности, интолерантности к новизне; в ранней юности - по интолерантности к неопределенности, интолерантности к новизне.

Половозрастная специфика выраженности связей толерантности к неопределенности с интернальностью и смысложизненными ориентациями

На выборке респондентов женского пола подросткового возраста наблюдается большая сеть связей интолерантности к неопределенности с интернальностью (рис. 2). Общий показатель интолерантности к неопределенности (ИТН) отрицательно связан с интернальностью в области производственных отношений (Ип; $r=-0,266$ при $\mathrm{p}<0,01)$ и межличностных отношений (Им; $r=-0,335$ при $\mathrm{p}<0,01)$. Толерантные к неопределенности девушкиподростки воспринимают свои действия в качестве влияющих на построение деловых и межличностных отношений. 
Горлова Н.В. Толерантность к неопределенности как индивидуально-личностная предпосылка...

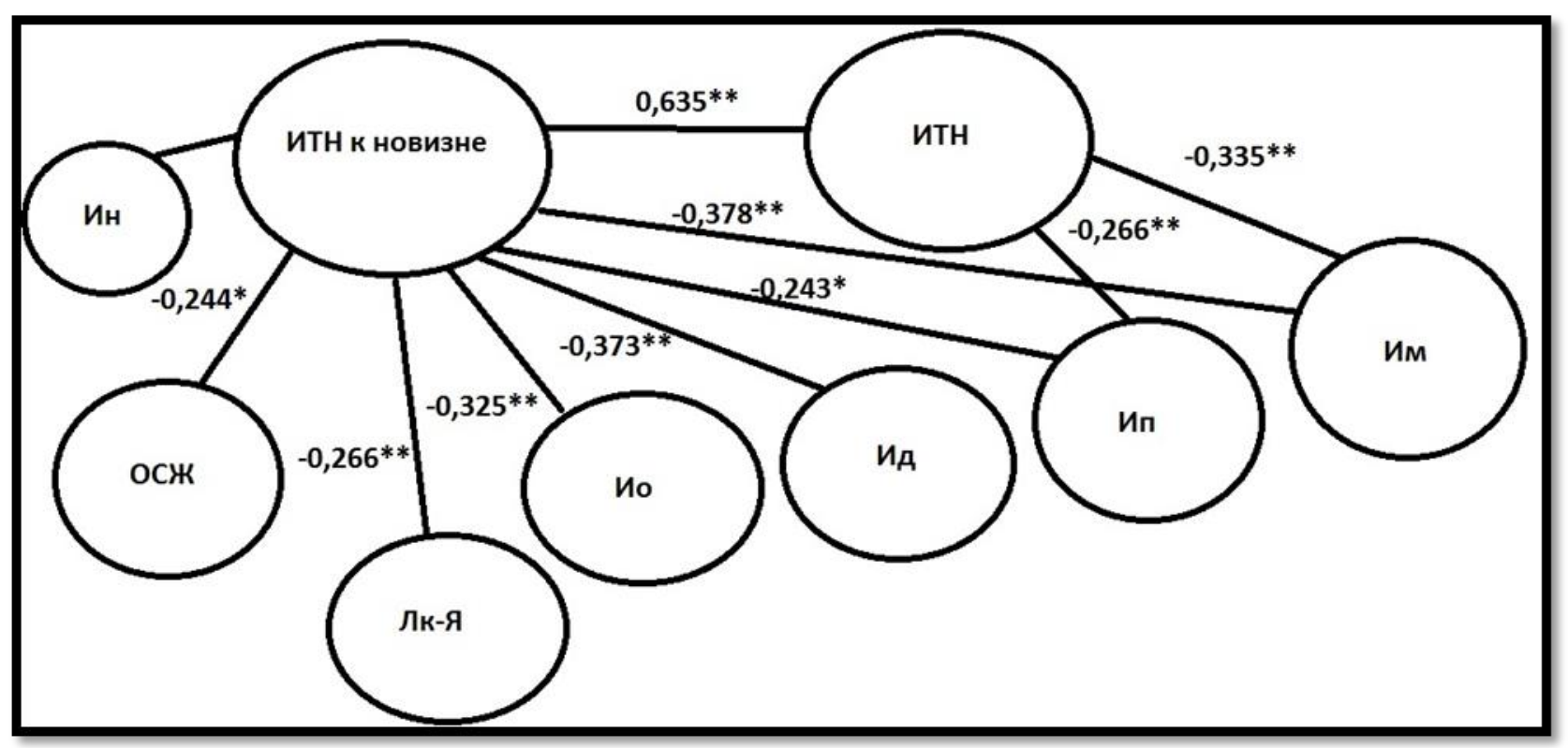

Рис. 2. Связи интолерантности к неопределенности, уровня субъективного контроля и смысложизненных ориентаций у респондентов женского пола, подростковый возраст.

Интолерантность к новизне (ИТН к новизне) отрицательно связана с общим показателем уровня субъективного контроля (Ио; $\mathrm{r}=-0,325$ при $\mathrm{p}<0,01)$, с интернальностью к достижениям (Ид; $r=-0,373$ при $\mathrm{p}<0,01)$, неудач (Ин; $r=-0,280$ при $\mathrm{p}<0,05)$ и также с интернальностью в области производственных отношений (Ип; $r=-0,243$ при $\mathrm{p}<0,05)$ и межличностных отношений (Им; $r=-0,378$ при $\mathrm{p}<0,01)$. Толерантные к новизне девушки подросткового возраста в целом имеют интернальный локус контроля, а также чувствуют свою ответственность за эмоционально положительные и отрицательные события и ситуации и за построение деловых и межличностных отношений.

Также интолерантность к новизне респондентов женского пола в подростковом возрасте отрицательно связана с общей осмысленностью жизни (ОСЖ; $r=-0,244$ при $\mathrm{p}<0,05)$ и локусом контроля-Я (Лк-Я; $r=-0,266$ при $\mathrm{p}<0,01)$ теста смысложизненных ориентаций. Девушки-подростки с высокой толерантностью к новизне также оценивают свою жизнь в целом как осмысленную и верят в свои силы, оценивая себя как сильную личность, которая обладает свободой выбора.

Связи компонентов интолерантности к неопределенности (интолерантности к новизне и сложности) на выборке респондентов мужского пола подросткового возраста представлены также достаточно обширно (рис. 3). 
Горлова Н.В. Толерантность к неопределенности как индивидуально-личностная предпосылка...

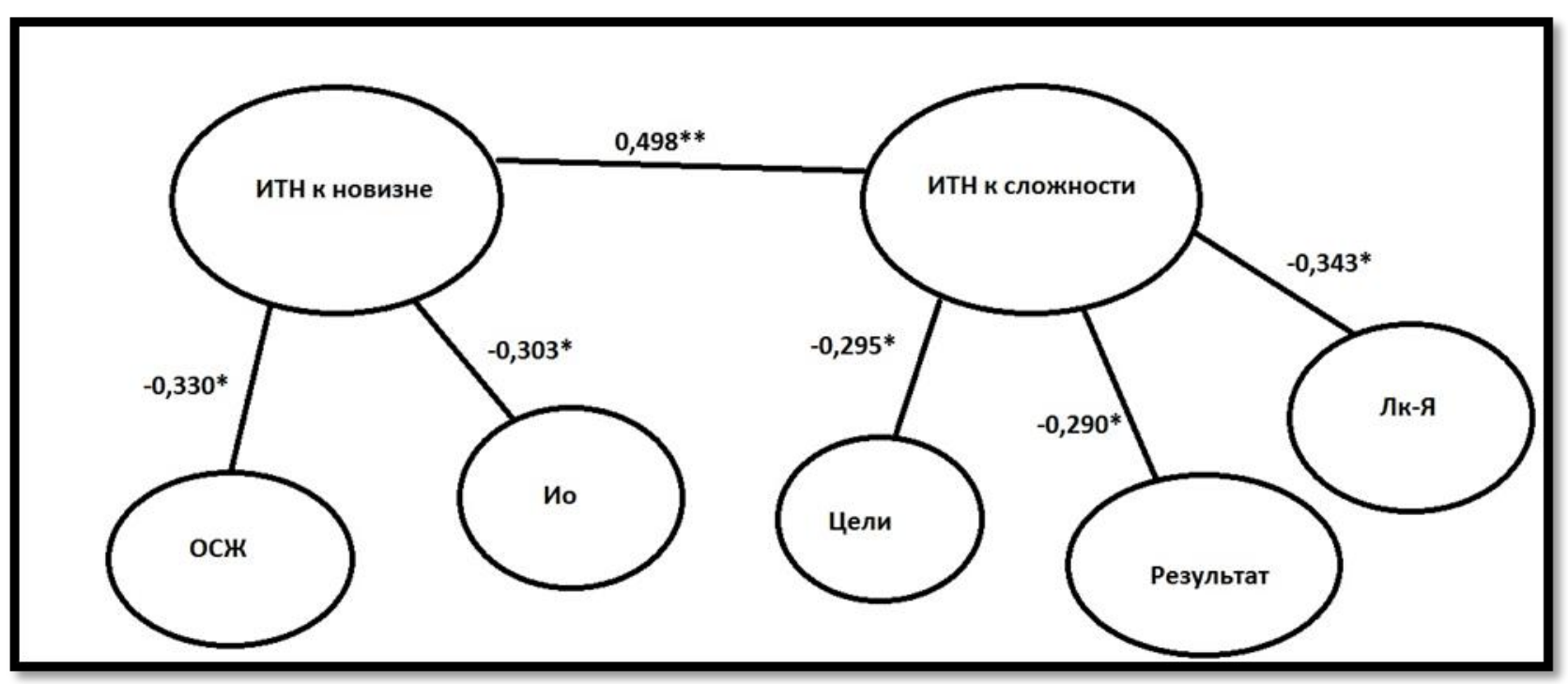

Рис. 3. Связи интолерантности к неопределенности, уровня субъективного контроля и смысложизненных ориентаций у респондентов мужского пола, подростковый возраст.

Интолерантность к новизне (ИТН к новизне) респондентов мужского пола подросткового возраста отрицательно связана с общим показателем уровня субъективного контроля (Ио; $\mathrm{r}=-0,303$ при $\mathrm{p}<0,05)$, а также с общей осмысленностью жизни (ОСЖ; $\mathrm{r}=-0,330$ при $\mathrm{p}<$ 0,05). Толерантные к новизне юноши-подростки в целом имеют интернальный локус контроля и оценивают свою жизнь в целом как осмысленную.

В отличие от респондентов женского пола у подростков мужского пола наблюдается связь интолерантности к сложности (ИТН к сложности) с тремя шкалами теста смысложизненных ориентаций - со шкалами «Цели» $(\mathrm{r}=-0,295$ при $\mathrm{p}<0,05)$, «Результат» $(\mathrm{r}=-0,290$ при $\mathrm{p}<0,05)$ и «Локус контроля-Я» (Лк-Я; $\mathrm{r}=-0,343$ при $\mathrm{p}<0,05)$. Толерантные к сложности юноши-подростки имеют цели в будущем, придающие жизни осмысленность, направленность и временную перспективу, оценивают пройденный отрез жизни как результативный, а также верят в свои силы, чувствуют себя сильными личностями, обладающими свободой выбора.

У девушек в ранней юности не наблюдается связей интолерантности к неопределенности и ее компонентов с уровнем субъективного контроля и смысложизненными ориентациями. Единственная положительная связь у респондентов мужского пола в ранней юности получена между общим показателем интолерантности к неопределенности (ИТН) и интернальностью в области неудач (Ин; $r=0,350$ при $\mathrm{p}<0,05)$. То есть интолерантные к неопределенности представители мужского пола в раннем юношеском возрасте оценивают 
Горлова Н.В. Толерантность к неопределенности как индивидуально-личностная предпосылка... свои неудачи как находящиеся в зоне собственной ответственности.

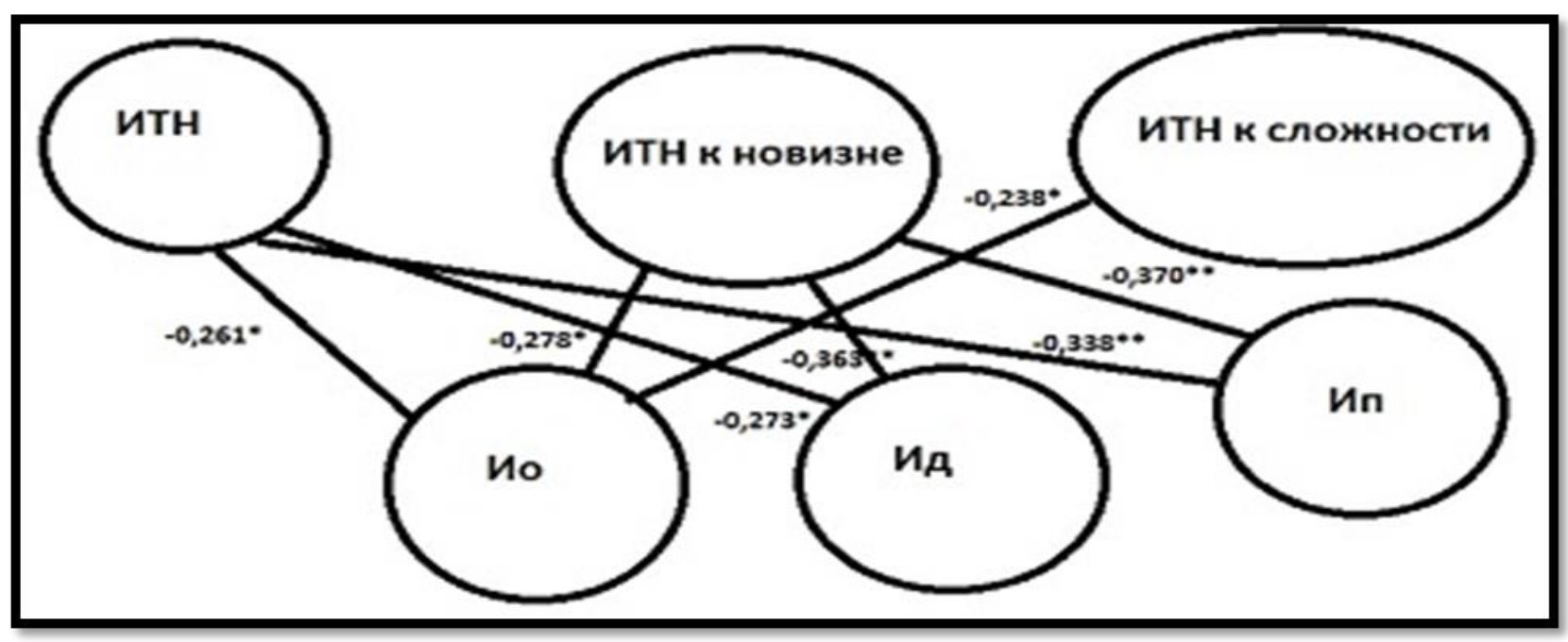

Рис. 4. Связи интолерантности к неопределенности, уровня субъективного контроля и смысложизненных ориентаций у респондентов женского пола, поздняя юность.

У респондентов женского пола в поздней юности (см. рис. 4) интолерантность к неопределенности (ИТН) отрицательно связана с общим показателем уровня субъективного контроля (Ио; $r=-0,261$ при $\mathrm{p}<0,05)$, интернальностью к достижениям (Ид; $r=-0,273$ при $\mathrm{p}<0,05)$, интернальностью в области производственных отношений (Ип; $r=-0,338$ при $\mathrm{p}<0,01)$. Интолерантность к новизне (ИТН к новизне) отрицательно связана с общим показателем уровня субъективного контроля (Ио; $\mathrm{r}=-0,278$ при $\mathrm{p}<0,05)$, интернальностью к достижениям (Ид; $\mathrm{r}=-0,363$ при $\mathrm{p}<0,01)$, интернальностью в области производственных отношений (Ип; $r=-0,370$ при $\mathrm{p}<0,01)$. Толерантные к неопределенности и новизне девушки в позднем юношеском возрасте в целом интернальны, а также имеют внутренний локус контроля к своим достижениям и считают, что ответственны за построение своих деловых отношений.

Интолерантность к сложности (ИТН к сложности) отрицательно связана с общим показателем уровня субъективного контроля (Ио; $r=-0,238$ при $\mathrm{p}<0,05)$. Связей интолерантности к неопределенности (ИТН) и ее компонентов со смысложизненными ориентациями (СЖО) у респондентов женского пола в поздней юности не получено. Толерантные к сложности девушки в позднем юношеском возрасте в целом имеют интернальный локус контроля.

\section{Обсужндение полученных результатов и выводы}

Психологические исследования 2020 T 13 № 70

http://psystudy.ru 15 
Горлова Н.В. Толерантность к неопределенности как индивидуально-личностная предпосылка...

Дисперсионный анализ показал, что респонденты женского пола более толерантны к неопределенности, чем респонденты мужского пола, в подростковом возрасте, в ранней и поздней юности. Это подтверждается и сравнением средних. В поздней юности толерантность к неопределенности у респондентов женского пола чуть снижается, и различия по этому показателю с респондентами мужского пола уже не достигают статистической значимости. Но в целом именно фактор пола, согласно проведенному исследованию, оказывает значимое влияние на толерантность к неопределенности на подростково-юношеском этапе взросления.

Что может означать с точки зрения процесса взросления высокая толерантность к неопределенности именно в выборке респондентов женского пола в исследовании? Основываясь на идее В.А.Петровского, что «надситуативная активность» - это маркер рождения человека как субъекта активности, можно предположить, что респонденты женского пола в подростково-юношеский период более личностно зрелые, чем респонденты мужского пола.

Итак, можно констатировать такие важные результаты исследования у респондентов женского пола подросткового возраста: 1) толерантные к неопределенности и к новизне респонденты женского пола берут ответственность за построение межличностных и производственных отношений на себя; 2) толерантные к новизне респонденты женского пола в целом берут ответственность в жизни на себя, ответственны за себя в области своих достижений и неудач; 3) толерантные к новизне респонденты женского пола чувствуют себя хозяйками жизни, представляют себя сильными личностями, которые обладают достаточной свободой выбора, чтобы построить свою жизнь в соответствии со своими целями и представлениями о ее смысле.

У респондентов женского пола в ранней юности не наблюдается связей толерантности к неопределенности ни с одной личностной переменной.

У респондентов женского пола в поздней юности толерантность к неопределенности опять имеет широкую сеть связей, сопоставимую со связями в подростковом возрасте: 1) толерантные к неопределенности респонденты женского пола, которые также терпимы к ситуациям с высокой новизной, в целом берут ответственность в жизни на себя, ответственность за свои достижения и за построение деловых отношений; 2) толерантные к Психологические исследования 2020 T 13 No 70 http://psystudy.ru 16 
Горлова Н.В. Толерантность к неопределенности как индивидуально-личностная предпосылка... сложности респонденты женского пола в целом берут на себя ответственность за свою жизнь.

Итак, получается, что у респондентов женского пола в подростковом возрасте и поздней юности толерантность к неопределенности и ее компоненты обширно связаны с уровнем субъективного контроля. То есть в этих возрастах у респондентов женского пола принятие неопределенности связано с ответственностью. Связь принятия неопределенности с ответственностью обсуждалась в работах В.П.Зинченко: неопределенность характерна для любой ситуации развития и становления человека, и лучше всего она преодолевается признанием ее существования, а также свободным, недетерминированным действием.

Сказанное не означает, что респонденты мужского пола на протяжении всего подростково-юношеского периода не показывают личностной зрелости. В подростковом возрасте толерантные к новизне респонденты мужского пола ответственны к своей жизни в целом и имеют высокую осмысленность жизни. Респонденты мужского пола подросткового возраста, толерантные к сложности, имеют цели в будущем, придающие их жизни осмысленность и временную перспективу, удовлетворены результативностью своей жизни, а также ощущают себя хозяевами жизни.

\section{Литература}

Андреева Г.М. Социальная психология сегодня: поиски и размышления. М.: Моск. психол.-соц. институт, 2009.

Бажин Е.Ф., Голынкина Е.Л., Эткинд А.М. Метод исследования уровня субъективного контроля. Психологический журнал, 1984, 5(3), 152-162.

Баташев А.Р. Смысловые конструкты восприятия социальной действительности подростками и юношеством и их трансформация в ходе ролевого моделирования. Вкн.: О.В. Лишин (Ред.), Российские подростки и юношество в социальной реальности XXI века: Личностное самоопределение, самореализация, взгляд на будущее. М.; Обнинск: ИГСОЦИН, 2008.

Блинникова С.Л. Психологическая природа понимания противоречий. Вопросы психологии, 2012, № 1, 52-62.

Волочков А.А., Ермоленко Е.Г. Ценностная направленность личности как выражение смыслообразующей активности. Психологический журнал, 2004, 25(2), 17-33. 
Горлова Н.В. Толерантность к неопределенности как индивидуально-личностная предпосылка... Дементий Л.И., Купченко В.Е. Типология жизненных стратегий в период юношества (на примере студентов вузов и колледжей). Психология обучения, 2011, No. 5, 44-53.

Зинченко В.П. Толерантность к неопределенности: новость или психологическая традиция? Вопросы психологии, 2007, №. 6, 3-20.

Калитеевская Е.Р., Леонтьев Д.А. Пути становления самодетерминации личности в подростковом возрасте. Вопросы психологии, 2006, No 3, 49-55.

Корнилова Т.В. Толерантность к неопределенности и интеллект как предпосылки креативности. Вопросы психологии, 2010, №. 5, 3-13.

Кроник А.А., Ахмеров Р.А. Каузометрия: Методы самопознания, психодиагностики и психотерапии в психологии жизненного пути. 2-е изд., испр. и доп.. М.: Смысл, 2008.

Леонтьев Д.А. Вызов неопределенности как центральная проблема психологии личности. Психологические исследования, 2015, No. 8(40), 2. http://psystudy.ru

Леонтьев Д.А. Психология смысла: природа, строение и динамика смысловой реальности. 3-е изд., доп. М.: Смысл, 2007.

Леонтьев Д.А. Тест смысложизненных ориентаций (СЖО). 2-е изд. М.: Смысл, 2006.

Леонтьев Д.А., Калитеевская Е.Р., Осин Е.Н. Личностный потенциал при переходе от детства к взрослости и становление детерминации. В кн.: Д.А. Леонтьев (Ред.), Личностный потенциал: структура и диагностика. М.: Смысл, 2011, 611-641.

Леонтьев Д.А., Овчинникова Е.Ю., Рассказова Е.И., Фам А.Х. Психология выбора. 2-е изд. стер. М.: Смысл, 2019.

Леонтьев Д.А., Шелобанова Е.В. Профессиональное самоопределение как построение образов возможного будущего. Вопросы психологии, 2001, № 1, 57-66.

Луковицкая Е.Г. Социально-психологическое значение толерантности к неопределенности: дис. ... канд. психол. наук. С.-Петерб. гос. университет, СПб., 1998.

Лэнгле А. Жизнь, наполненная смыслом. Прикладная логотерапия. 4-е изд. М.: Генезис, 2011.

Панцырь С.Н. Внутриличностные конфликты подростков с девиантным поведением: дис. ... канд. психол. наук. Моск. гор. психол.-пед. ин-т, М., 2012.

Петровский В.А. Человек над ситуацией. М.: Смысл, 2010.

Сафин В.Ф., Нурлыгаянов И.Н. Структура и содержание ценностно-смысловой сферы при разных типах самоопределения личности. Сибирский психологический журнал, 2008, No 27, 18-23.

Смирнов С.Д., Чумакова М.А., Корнилова Т.В. Образ мира в динамическом контроле неопределенности. Вопросы психологии, 2016, № 4, 3-13.

Солдатова Г.У., Шайгерова Л.А., Прокофьева Т.Ю., Кравцова О.А. (Ред.). ПсиходиагноПсихологические исследования 2020 T 13 No 70

http://psystudy.ru 
Горлова Н.В. Толерантность к неопределенности как индивидуально-личностная предпосылка... стика толерантности личности. М.: Смысл, 2008.

Сырцова А. Возрастная динамика временной перспективы личности: дис. ... канд. психол. наук. Моск. гор. психол.-пед. ин-т, М., 2008.

Тропотяга П.А. Локус контроля и эмоциональное отношение к будущему как психологические предпосылки профессионального становления личности. Сибирский психологический журнал, 2008, № 27, 102-106.

Фромм Э. Душа человека. Сб.: Пер. с англ. / Э.Фромм. М.: АСТ: Транзиткнига, 2004.

Хазова С.А. Ментальные ресурсы субъекта в разные возрастные периоды: дис. ... д-ра психол. наук. Ин-т психологии РАН. М., 2014.

Ялом И.Д. Экзистенциальная психотерапия. М.: Класс, 1999.

Bronk K.S., Hill P.L., Lapsley D.K., Talib T.L., Finch H. Purpose, hope, and life satisfaction in three age groups. The Journal of Positive Psychology, November 2009, 4(6), 500-510. doi:10.1080/17439760903271439

Crumbaugh J.S., Maholick L.T. An experimental study in existentialism: The psychometric approach to Frankl's concept of noogenic neurosis. Journal of Clinical Psychology, 1964, 20(2), 200-207.

Damon W., Menon J., Bronk K.C. The Development of Purpose During Adolescence. Applied Developmental Science, 2003, 7(3), 119-128. doi:10.1207/S1532480XADS0703_2

Gillham J., Adams-Deutsch Z., Werner J., Reivich K., Coulter-Heindl V., Linkins M., Winder B., Peterson C., Park N., Abenavoli R., Contero A., Seligman M.E.P. Character strengths predict subjective well-being during adolescence. The Journal of Positive Psychology, January 2011, 6(1), 31-44. doi:10.1080/17439760.2010.536773

Gorlova N., Romanyuk L., Vanbrabant L., van de Schoot R. Meaning-in-life orientations and values in Youth: cross-cultural comparison. European Journal of Developmental Psychology, 2012, 9(6), 744-750. doi:10.1080/17405629.2012.689823

Hill P.L., Burrow A.L., O’Dell A.C., Thornton M.A. Classifying adolescents' conceptions of purpose in life. The Journal of Positive Psychology, November 2010, 5(6), 466-473. doi:10.1080/17439760.2010.534488

Leontiev D.A. The phenomenon of choice: Preliminary considerations. Sharing tools for personal. In: V. Kagan (Ed.), Global Harmony: First Annual Conference on Conflict Resolution. St.Peterburg, 1994. pp. 52-64.

Ryan R.M., Deci E.L. Self-determination theory and the facilitation of intrinsic motivation, social development, and well-being. American Psychologist, 2000, No. 55, 68-78.

Steger M.F., Frazier P., Oishi S., Kaler M. The Meaning in Life Questionnaire: Assessing the presence of and search for meaning in life. Journal of Counseling Psychology, 2006, No. 53, 80Психологические исследования 2020 T 13 No 70

http://psystudy.ru 
Горлова Н.В. Толерантность к неопределенности как индивидуально-личностная предпосылка... 93. doi:10.1037/0022-0167.53.1.80

Tirria K., Quinn B. Exploring the role of religion and spirituality in the development of purpose: case studies of purposeful youth. British Journal of Religious Education, September 2010, 32(3), 201-214. doi:10.1080/01416200.2010.498607

Поступила в редакцию 19 марта 2020 г. Дата публикации: 14 мая 2020 г.

\section{Сведения об авторе}

Горлова Наталья Владимировна. Заведующий центром развития профессиональных компетенций руководителей и системных изменений в образовании, Краевое государственное автономное учреждение дополнительного профессионального образования «Красноярский краевой институт повышения квалификации и профессиональной переподготовки работников образования», ул. Матросова 19, 660079, Красноярск, Россия.

E-mail: gorlova_n@mail.ru

\section{Ссылка для цитирования}

Горлова Н.В. Толерантность к неопределенности как индивидуально-личностная предпосылка процесса самоопределения в подростковом возрасте, ранней и поздней юности// Психологические исследования. 2020. Т. 13, № 70, C. 5. URL: http://psystudy.ru

\section{Адрес статьи}

http://psystudy.ru/index.php/num/2020v13n70/1743-gorlova70.html 